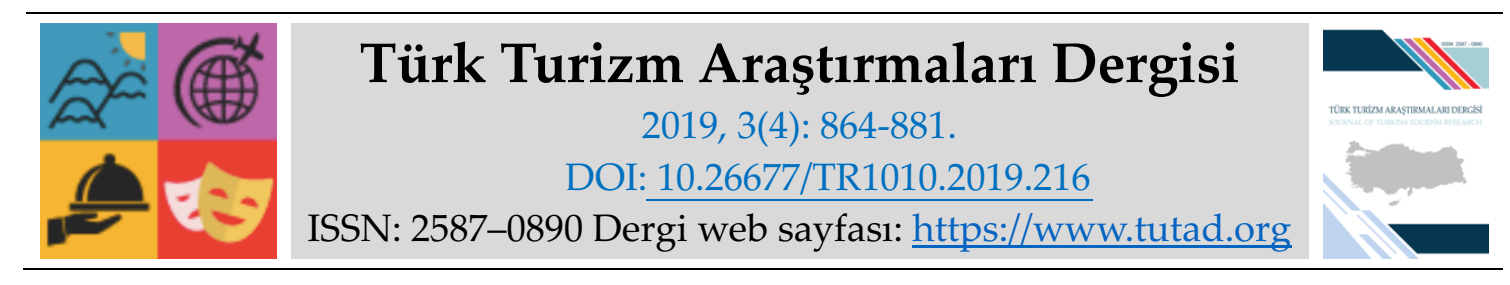

ARAȘTIRMA MAKALESI

\title{
Lisans Düzeyinde Turizm Eğitimi Alan Öğrencilerin Sosyal Medya Kullanımları Üzerine Bir Araştırma: Çanakkale Onsekiz Mart Üniversitesi Örneği*
}

Arş. Gör. Oğuzhan DÜLGAROĞLU, Çanakkale Onsekiz Mart Üniversitesi, Turizm Fakültesi, Çanakkale, e-posta: odulgaroglu@comu.edu.tr

ORCID: https://orcid.org/0000-0002-1992-0531

Doç. Dr. Lütfi ATAY, Çanakkale Onsekiz Mart Üniversitesi, Turizm Fakültesi, Çanakkale, eposta: lutfiatay@yahoo.com

ORCID: https://orcid.org/0000-0003-2598-6227

Dr. Öğr. Üyesi Hacı Mehmet YILDIRIM, Çanakkale Onsekiz Mart Üniversitesi, Turizm Fakültesi, Çanakkale, e-posta: $\underline{\text { h.mehmet@comu.edu.tr }}$

ORCID: https://orcid.org/0000-0003-0718-7296

$\ddot{O} z$

İletişim, insanların birbirleriyle anlaşma yoluna gidebilmeleri, işlerin düzgün ve doğru bir biçimde gerçekleştirilebilmesi adına kilit bir konuma sahiptir. Son zamanlarda teknolojinin de gelişim göstermesiyle beraber bireyler arasındaki iletişim çoğunlukla sosyal medya araçları vasıtasıyla sağlanabilmektedir. Sosyal medya araçları aracılığıyla bireyler kendi aralarında belli uygulamalarla bilgi paylaşımında bulunabilmektedirler. Özellikle $Z$ ve $Y$ kuşağı olarak belirtilen genç bireylerin sosyal medya uygulamalarıyla çok yakın bir ilişki içinde olduğu görülmektedir. Gerçekleştirilen bu çalışmada lisans seviyesinde turizm eğitimi alan öğrencilerin sosyal medyayı kullanma amaçları ve alışkanlıklarının saptanması hedeflenmektedir. Çalışma nicel araştırma olup, veriler anket formları ile toplanmıştır. Çalışmanın örneklemini Çanakkale Onsekiz Mart Üniversitesi Turizm Fakültesi öğrencileri oluşturmaktadır. Verilerin analizi sonucu ortaya çıkan bulgulara göre; lisans düzeyinde turizm eğitimi alan öğrencilerin sosyal medyayı kullanma amaçları ve alışkanlıklarının beş boyuttan oluştuğu tespit edilmiştir. Bu boyutlar sırasıyla; eğlence, bilgi edinme, fayda sağlama, sosyalleşme ve sanallaştırmadır. Bununla birlikte lisans düzeyinde turizm eğitimi alan öğrencilerin sosyal medyayı kullanma amaçları ve alışkanlıklarının öğrencilerin özelliklerine göre farklılık gösterdiği ve öğrencilerin sosyal medyadan fayda sağlamasında eğlence ve bilgi edinme boyutlarının etkili olduğu tespit edilmiştir.

*Bu çalışma, 17-19 Temmuz 2018 tarihinde Kastamonu'da düzenlenen 4. Uluslararası Türk Dünyası Turizm Sempozyumu'nda özet bildiri olarak sunulmuştur.

Anahtar Kelimeler: Turizm Eğitimi, Sosyal Medya, İnternet, Teknoloji, İletişim.

Makale Gönderme Tarihi: 20.05.2019

Makale Kabul Tarihi: 01.10.2019

Önerilen Atıf:

Dülgaroğlu, O., Atay, L. ve Yıldırım, H. M. (2019). Lisans Düzeyinde Turizm Eğitimi Alan Öğrencilerin Sosyal Medya Kullanımları Üzerine Bir Araştırma: Çanakkale Onsekiz Mart Üniversitesi Örneği, Türk Turizm Araştırmaları Dergisi, 3(4): 864-881.

(C) 2019 Türk Turizm Araştırmaları Dergisi. 


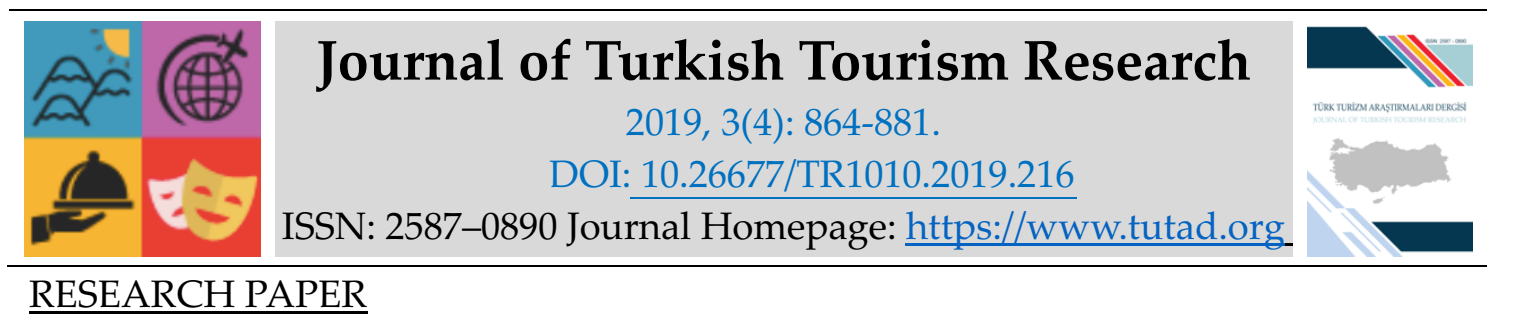

\title{
A Research Towards Social Media Uses of Undergraduate Tourism Students: The Case of Çanakkale Onsekiz Mart University
}

Research Assistant Oğuzhan DÜLGAROĞLU, Çanakkale Onsekiz Mart University, Faculty of Tourism, Çanakkale, e-mail: odulgaroglu@comu.edu.tr

ORCID: https://orcid.org/0000-0002-1992-0531

Associate Prof. Dr. Lütfi ATAY, Çanakkale Onsekiz Mart University, Faculty of Tourism, Çanakkale, e-mail: lutfiatay@yahoo.com

ORCID: https://orcid.org/0000-0003-2598-6227

Assistant Prof. Dr. Hacı Mehmet YILDIRIM, Çanakkale Onsekiz Mart University, Faculty of Tourism, Çanakkale, e-mail: h.mehmet@comu.edu.tr

ORCID: https://orcid.org/0000-0003-0718-7296

\begin{abstract}
Communication has a key position for people to be able to negotiate with each other and to make things work accurately and properly. Recently, with the development of the technology, inter-individual communication can be provided mostly through social media tools. Through social media channels, individuals can share information with certain tools among themselves. It is seen that especially young people who are mentioned as $\mathrm{Y}$ and $\mathrm{Z}$ generations have a very close relationship with social media. In this study, it is aim to determine the social media usage purposes and praxizes of the tourism students who are at the undergraduate level. The study is a qualitative research. In this study, questionnaire forms were used as data collection tools. The sample of the study consisted of the students of Çanakkale Onsekiz Mart University Tourism Faculty. As a result of the analysis of the obtained data, it was determined that the social media usage purposes and prazies of social media of undergraduate tourism students consist of five dimensions. These dimensions are called entertainment, information, benefit, socialization and virtualization, respectively. In the meantime, it was determined that social media usage purposes and praxizes of undergraduate tourism students differ according to their various features. It was also determined that the dimensions of entertainment and knowledge were effective in benefiting from social media.
\end{abstract}

Keywords: Tourism Education, Social Media, Internet, Technology, Communication.

Received: 20.05.2019

Accepted: 01.10.2019

\section{Suggested Citation:}

Dülgaroğlu, O., Atay, L. and Yıldırım, H. M. (2019). A Research Towards Social Media Uses of Undergraduate Tourism Students: The Case of Çanakkale Onsekiz Mart University, Journal of Turkish Tourism Research, 3(4): 864-881.

(C) 2019 Türk Turizm Araştırmaları Dergisi. 


\section{Gíriş}

İnternetin keşfi ve 1980'li yıllarda insanlığın hizmetine sunulması, 20. yüzyıla damgasını vuran önemli dönüm noktalarından birisi olarak değerlendirilebilir. Bilgisayarın icadından sonra iletişim uyduları aracılığıyla gelişen teknolojinin birleşmesinden türeyen bu yeni iletişim olgu ve süreci, çağımıza "Bilgi Çağı" isminin verilmesine sebep olmuştur (Aziz, 2008: 71). Bilgi çağında gelişen internetin, kişilerin bilgileri daha kolay elde etme fırsatı bulmalarına ve kendi aralarında daha kolay iletişim kurmalarına sebep olduğu söylenebilir.

İnternet sunduğu imkanlarla geleneksel medyadan farklılaşmaktadır. Televizyon ve yazılı basın gibi geleneksel iletişim kanalları görsel açıdan etkileyici olabilmekle birlikte, tek yönlü bir iletişim kurdukları için amaca ulaşma konusunda yönlendirici olmaktadır. İnternetin sağladığı web uygulamalarındaysa iletişim kuran bireyler arasında eş zamanlı ve iki yönlü bilgi akışı sağlanmaktadır (Sayımer; 2008: 29; Dickey, Lewis ve Siemens, 2008). Bu enformasyon akışının sağlandığı ortamlardan biri de sosyal medyadır.

Son zamanlarda "sosyal medya" olarak tanımlanan internet tabanlı uygulamalar vasıtasıyla, kullanıcıların kendi aralarında paylaştıkları içeriklerle sağladıkları iletişimin gün geçtikçe arttığı görülmektedir. Bu içerikler metin, fotoğraf, video ve medyaya ilişkin karışık oluşumları kapsamaktadır (Komito ve Bates, 2009: 233; Kaplan ve Haenlein, 2010). Sosyal medya zaman ve mekân sınırlaması olmadan paylaşımın ve tartışmanın esas olduğu bir iletişim şeklidir (Hart ve Blackshaw, 2006; Vural ve Bat, 2010). Sosyal medya vasitasiyla kişiler birbirleriyle kolayca iletişim kurabilmekte ve durumlarla ilgili yorumlarını birçok kişinin görebileceği bu platformlarda paylaşabilmektedirler. Özellikle teknolojiyle iç içe yetişen ve teknolojiyle büyüyen $\mathrm{Y}$ ve $\mathrm{Z}$ kuşakları sosyal medyayla çok erken yaşlarda tanışma fırsatı bulabildiğinden, birbirleriyle iletişimi sosyal medya kanalları aracılığıyla kurmaktadırlar. Bu çalışmada $X$ ve $Y$ kuşağından oluşan lisans seviyesinde turizm eğitimi alan öğrencilerin sosyal medyayı kullanma amaçları ve alışkanlıkları tespit edilmeye çalışılmaktadır.

\section{KURAMSAL ÇERÇEVE}

Bu kısımda alanyazındaki kaynaklardan faydalanılarak teknoloji ve yaşam ile internet ve sosyal medyaya değinilecektir.

\section{Teknoloji ve Yaşam}

Teknolojinin, günümüzdeki algıyla daha çok yüksek niteliğe sahip bilimsel bilgi ve tekniği kapsayan ürünler olarak algılandığı söylenebilir. Günlük dilde, yazılı ve görsel basında karşımıza bu şekilde çıksa da teknoloji teknik bilginin yaşama geçirilmesini öngören tüm toplumsal ve ekonomik etkinlikler ve örgütlenmeleri de kapsayan bir alan olarak tanımlanabilir. İyimser bir açıdan bakıldığında teknoloji, bilimsel ilke ve yeniliklerle birlikte problemlerin çözümünün sağlanmasına yönelik uygulamalar olarak düşünülebilir. Başka bir ifadeyle teknoloji, bilimin bir uygulamasıdır (Goetsch, 1984; Hughes, 2012). Bilgisayarlar, robotlar ve uydular bilimin sorunların çözümü için uygulanması sonucu meydana çıan araçlar olarak görülebilir. Gelişen teknolojiyle birlikte kişilerin bilgi toplamalarının daha kolay bir hale geldiği görülmektedir.

Bilginin toplanması, üretilmesi, işlenmesi, düzenli ve sistematik bir şekilde depolanması, aralarında ilişki kurularak doğru ve hızlı bir biçimde erişilmesi, ağlar aracılığıyla iletilmesi ve kullanım hizmetine sunulmasında yararlanılan iletişim teknolojilerini içine alan genel ifade 
'bilgi ve iletişim teknolojileri' olarak isimlendirilmektedir (Atılgan, 2006; Vermesan ve Friess, 2013; Kuyucu, 2015; Sütlüoğlu, 2015; Yu, Ellison ve Mc Cammon, 2016; Soylu, 2018). Bilgi ve iletişim teknolojileri sayesinde kişilerin evlerindeki bilgisayarlar ve ellerindeki cep telefonlarıla rahatlıkla iletişim kurabildikleri, birbirlerine fotoğraf veya video gönderebildikleri ve hatta oldukları yerden canlı yayın dahi yapabildikleri görülmektedir.

Yakın zaman dilimlerinde doğan, birçok önemli etmeni etkileyen ve birçok önemli etmenden etkilenen ortak deneyimleri paylaşan bir grup birey veya topluluğa kuşak adı verilmektedir (Kupperschmidt, 2000). Lower (2008: 81) her kuşağın kendine has özellikleri, değer yargıları, tutumları, kuvvetli ve zayıf yönlerinin olduğunu belirtmiştir. Araştırmacılar kuşakları belirli tarihsel dönemler içerisinde değerlendirmişler ve kuşaklar her dönem içinde farklı isimlerle sınıflandırılmıştır. Geçmişten bugüne kuşaklar beş farklı grup altında sınıflandırılmıştır. Bunlar: Gelenekselciler Kuşağı (1927-1945 yılları arasında doğanlar), Büyük Bebek Patlaması Kuşağı (1946-1965 yılları arasında doğanlar), X Kuşağı (1965-1979 yılları arasında doğanlar), Y Kuşağ1 (1979-1999 yılları arasında doğanlar) ve Z Kuşağı (2000 ve sonraki yıllarda doğanlar) olarak beş sinıfta belirtilmiştir (Williams ve Page, 2011: 2).

İnternet teknolojisinin gelişmesinde önemli adımlar atan $X$ kuşağından sonra ortaya çıkan $Y$ kuşağının, $X$ kuşağının ortaya çıkardığı iletişim teknolojilerini kullanma şansına sahip olduğu görülmektedir. Y kuşağının yaşam şeklinin teknolojiyle paralel geliştiği söylenebilir. $Y$ kuşağının, elindeki cep telefonu vasıtasıyla farklı kanalları kullanma yoluna giderek birbirleriyle daha kolay iletişim kurma şansını yakaladığı görülmektedir. Önceki kuşaklar gazetelerin ilk baskısından haberleri öğrenme fırsatı bulurken, Y Kuşağı ellindeki akıllı telefonlar sayesinde anında ve hızlı bir şekilde gündemden haberdar olabilme fırsatına sahiptir. Web 2.0 teknolojilerinde yaşanan gelişmeler ışığında internet teknolojisi ile daha iç içe bir hayat yaşayan $Y$ kuşağı için teknoloji hayatın vazgeçilmez unsurlarından biri olmuştur (Kuyucu, 2017; Bolton vd., 2013). Tıpkı Y kuşağı gibi Z kuşağı da teknolojiyle iç içe büyüme fırsatı bulduğu için bilgi ve iletişim teknolojilerine karşı her iki kuşağın da oldukça ilgili oldukları gözlemlenmektedir. Bu durum Y ve Z kuşaklarının sosyal medya kullanımlarını destekleyici bir etken olarak kabul edilebilir. Alanyazında da birçok çalışmada $Y$ ve $Z$ gibi genç kuşakların diğer kuşaklara göre sosyal medyayı daha fazla kullandığı vurgulanmıştır (Chakraborty, Vishik ve Rao, 2013; Hayes, Van Stolk-Cooke ve Muench, 2015; Yang ve Jolly, 2015).

\section{İnternet ve Sosyal Medya}

İnternet hakkında birçok tanımın yapıldığı görülmektedir. Bu tanımlardan bazılarına göre internet; birçok bilgisayar sisteminin birbiriyle bağlı olduğu, dünya çapında yayılmış olan ve sürekli büyüme eğiliminde olan bir alandır (Weinberg, 2009: 1; Vermesan ve Friess, 2013; Yu vd., 2016; Seifert, Doh ve Wahl, 2017; Soylu, 2018). Hayatımızın vazgeçilmezlerinden biri olan internet teknolojisinin özellikleri şu şekilde özetlenebilir (Aziz, 2008: 72):

- İnternet, iletişim teknolojilerinin bir toplanma merkezidir.

- Yazılı iletişim araçları, iletişim uyduları, telefon, yazıll, kitle iletişim araçları, kitap, fotoğraf, bilgi kaydetme ve bilgi depolama teknikleri gibi tüm iletişim tekniklerini kullanır.

- İnternet tün medya özelliklerini yerine getirir.

- İnternet ticari fırsatlar ortaya çıkarır.

- İnternet etkileşimli bir şekilde iletişim sağlar. 
İnternetin gelişmesiyle beraber sosyal medyanın da hızla gelişme gösterdiği görülmektedir. Sosyal medya, bilginin, farklı bakışların veya düşüncelerin ve deneyimlerin kamu oluşumlu web siteleri vasıtasıyla paylaşımına olanak sağlayan, internet dünyasını hızlı bir şekilde yaşamımızda bir yer edinmesini sağlayan bir uygulama alanıdır (Weinberg, 2009: 1). Sosyal medya; kullanıcıların bilgilerini, görgülerini, ilgi alanlarını internet ya da mobil sistemler vasıtasıyla paylaştıkları sosyal platformlar olarak tanımlanmaktadır (Eröz ve Doğdubay, 2012).

Sosyal medya, isminde medya olmasına rağmen geleneksel medyadan birtakım farklı özellikler barındırabilmektedir. Sosyal medyanın özgünlügüünü ortaya çıkaran en önemli farklılıkları, herhangi bir kişinin sosyal medyanın içeriğini yaratabilmesi, bu mecrada yorumda bulunabilmesi ve yaratılan içeriğin etkileşimine katkı sağlayabilmesidir (Scott, 2010:38). Sosyal medya fazlasıyla paylaşımın gerçekleştiği, çevrimiçi medyanın yeni bir çeşidi olarak fırsatlar yarattığı en yeni fikirlerden biridir ve şu özellikleri içerir (Mayfield, 2008):

- Katılımcılar: Sosyal medya katılımciları cesaretlendirir ve konularla ilgili olan her bir kullanıcıdan geri bildirim alır.

- Açıklık: Sosyal medya servisleri geri bildirime ve katılımcılara açıktır. Bu servisler oylama, yorum yapma ve bilgi paylaşımı gibi konularda kişilere cesaret aşılarlar. Bunlarda ulaşıma yönelik engeller çok nadirdir.

- Konuşma: Geleneksel medya içerik aktarımı ya da dinleyiciye bilgi ulaşımına ilişkinken, sosyal medya iki yönlü konuşmaya olanak tanıyabilmesi bakımından daha üstündür.

- Toplum: Sosyal medya topluluklara hızlı ve etkili bir oluşum için izin verir. Topluluklar da böylece kendi aralarında sevdikleri fotoğraf, politik değerler, favori TV şovları gibi ilgili oldukları şeyleri paylaşma fırsatı bulurlar.

- Bağlantılılık: Sosyal medyanın çoğu türü, bağlantılı işler gerçekleştirir. Sosyal medya vasıtasıyla kişiler diğer siteler, araştırmalar ve insanların ilgili oldukları herhangi bir konu hakkında başkalarına bağlantı adresi gönderebilir.

Sosyal medya platformları genel olarak; tartışma forumları, sohbet odaları, bulunulan konuma dayalı hizmetler, sosyal ağ hizmetleri, sosyal imleme, sosyal rehberler, sosyal itibar ağları, bloglar, video paylaşım uygulamaları, facebook, instagram ve twitter gibi uygulamaları kapsamaktadır. Bu örnekler gün geçtikçe çoğaltılabilir.

\section{YÖNTEM}

Araştırmanın evrenini lisans düzeyinde turizm eğitimi alan öğrenciler oluşturmaktadır. Araştırmanın örneklemini ise kolayda örnekleme yöntemine başvurularak ulaşılan, Çanakkale Onsekiz Mart Üniversitesi Turizm Fakültesi'nde lisans seviyesinde turizm eğitimi almakta olan 487 öğrenci oluşturmaktadır. Örneklem olarak turizm eğitimi almakta olan öğrencilerin seçilmesinde, sosyal medyada oldukça aktif olduklarının gözlemlenmesi etkili olmuştur.

Araştırma kapsamında, veriler 1-25 Mayıs 2018 tarihleri arasında anket formu vasıtasıyla elde edilmiştir. Turizm öğrencilerine yönelik oluşturulan anket, öğrencilerin sosyal medyayı kullanma amaçları ve alışkanlıkları, sosyal medya türlerini kullanım sıklıkları, kullanma öncelikleri ve sosyo-demografik özellikleri olmak üzere dört farklı bölümden oluşmaktadır. Sosyal medya kullanım amaçları ve alışkanlıklarıyla ilgili toplam 22, sosyal medya türleriyle ilgili 10, sosyo-demografik özelliklerle ilgili dört ifade öğrencilere yöneltilmiş, birinci ve ikinci bölümdeki ifadeleri beşli likert ölçeğine göre doldurmaları, üçüncü bölümde sosyal medya araçlarını kullanma önceliklerine göre sıralamaları, dördüncü bölümde ise kendi sosyodemografik özelliklerine göre doldurmaları istenmiştir. Anket formunun birinci bölümünde yer 
alan sosyal medyayı kullanma amaçları ve alışkanlıklarıyla ilgili ilk 16 ifade Papacharissi ve Rubin (2000)'in internet kullanım motivasyonu üzerine gerçekleştirdikleri çalışmalarından alınmıştır. Öğrencilerin sosyal medyayı kullanma amaçları ve alışkanlıklarına ilişkin son altı ifade ise yazarlar tarafından hazırlanmıştır. Anket uygulaması için 520 adet öğrenciye dağıtılan anketlerden 501 tanesinden geriye dönüş sağlanmış, fakat öğrencilerin hatalı ya da eksik cevap vermelerinden dolayı 14 anket değerlendirmeye alınmamıştır. Geriye kalan 487 adet anket formundan elde edilen veriler analize dahil edilmiştir.

Çalışmada ölçeğin güvenilirliği, Cronbach Alpha katsayısı bulunarak sağlanmıştır. Yapılan analiz sonunda çalışmada kullanılan ölçeğin Cronbach Alpha katsayısı ,811 olarak bulunmuştur. Çalışmada geçerlilik ise uzman görüşünden faydalanarak sağlanmıştır. Toplanan verilere öncelikle normallik testi uygulanmıştır. Elde edilen verilerin çarpıklık ve basıklık değerleri -1.500 ile 1.500 arasında bulunduğu için normal dağılım gösterdikleri tespit edilmiştir. Öğrencilerin sosyal medyayı kullanma amaçları ve alışkanlıklarının tespiti için veri setine faktör analizi yapılmıştır. Faktör analizi, birbirleriyle ilişkisi bulunan verileri, birbirinden bağımsız daha az sayıda yeni veri ortaya çıarma amacıyla kullanılmaktadır (Özdamar, 2004). Bu analiz vasıtasıyla, olayları açıladıkları düşünülen ifadeler, çeşitli faktörlerin çatısı altında boyutlandırılarak açığa çıkarılmaya çalışılmaktadır. Daha sonra lisans seviyesinde turizm eğitimi almakta olan öğrencilerin sosyal medyayı kullanma amaçları ve alışkanlıklarının betimleyici özelliklerine göre farklılık gösterip göstermediklerini tespit etmek amacıyla t-testi ve tek yönlü varyans analizi (ANOVA) yöntemlerine başvurulmuştur. Bu çalışmada şu hipotezler kurulmuştur:

Hı: Öğrencilerin sosyal medyayı kullanma amaçları ve alışkanlıkları cinsiyetlerine göre farklılık göstermektedir.

$\mathrm{H}_{2}$ : Öğrencilerin sosyal medyayı kullanma amaçları ve alışkanlıkları uyruklarına göre farklılık göstermektedir.

$\mathrm{H}_{3}$ : Öğrencilerin sosyal medyayı kullanma amaçları ve alışkanlıkları okudukları bölümlere göre farklılık göstermektedir.

$\mathrm{H}_{4}$ : Öğrencilerin sosyal medyayı kullanma amaçları ve alışkanlıkları hangi sınıfta okuduklarına göre farklılık göstermektedir.

H5: Lisans seviyesinde turizm eğitimi almakta olan öğrencilerin sosyal medyada elde ettiği faydada eğlence, bilgi edinme ve sosyalleşme etkilidir.

\section{BULGULAR}

Lisans seviyesinde turizm eğitimi almakta olan öğrencilerin sosyal medyayı kullanma amaçları ve alışkanlıklarının tespit edilmeye çalışıldığı çalışmada, anket formlarından elde edilen verilerin değerlendirilmesi ile ortaya çıkan bulgulara göre; araştırmaya katılan öğrencilere ait betimleyici özellikler Tablo 1'deki gibidir.

Tablo 1'e bakıldığında çalışmaya katılım gösteren öğrenciler \%47'si kadın, \%53'ü ise erkek katılımcılardan oluşmaktadır. Çalışmaya katılan katılımcılardan \%95,9'u yerli, \%4,1'i ise yabancı uyrukludur. Çalışmaya katılan katılımcıların \%44,1'i Turizm İşletmeciliği, \%55,9'u ise Seyahat İşletmeciliği ve Turizm Rehberliği bölümlerinde lisans düzeyinde öğrenim görmektedir. Katılımcılar arasında birinci sınıf öğrencisi oranı \%27,9, ikinci sınıf öğrencisi oranı $\% 24,2$, 
üçüncü sınıf öğrencisi oranı \%27,3 ve dördüncü sınıf öğrencisi oranı \%20,5'dir. Tüm bu oranlara bakıldığında katılımcılara ilişkin betimleyici bulguların analiz yapmaya elverişli olduğu söylenebilir.

Tablo 1. Katılımcılara İlişkin Betimleyici Bulgular $(\mathrm{N}=487)$

\begin{tabular}{|l|l|l|}
\hline Cinsiyet & $\mathbf{N}$ & $\mathbf{\%}$ \\
\hline Kadın & 229 & 47 \\
\hline Erkek & 258 & 53 \\
\hline Bölüm & $\mathbf{N}$ & $\mathbf{\%}$ \\
\hline Turizm İşletmeciliği & 215 & 44,1 \\
\hline Seyahat İşletmecilï̆i ve Turizm Rehberliği & 272 & 55,9 \\
\hline Sinıf & $\mathbf{N}$ & $\mathbf{\%}$ \\
\hline 1. Sinıf & 136 & 27,9 \\
\hline 2. Sinıf & 118 & 24,2 \\
\hline 3. Sinıf & 133 & 27,3 \\
\hline 4. Sinıf & 100 & 20,5 \\
\hline Uyruk & $\mathbf{N}$ & $\mathbf{\%}$ \\
\hline Yerli & 467 & 95,9 \\
\hline Yabancı & 20 & 4,1 \\
\hline
\end{tabular}

Tablo 2. Öğrencilerin Öncelik Sırasına Göre Sosyal Medya Araçları

\begin{tabular}{|l|c|c|}
\hline \multirow{2}{*}{ Sosyal Medya Araci } & \multicolumn{3}{|l|}{$\mathbf{1 . ~ T e r c i h}$} \\
\cline { 2 - 3 } & N & \% \\
\hline Instagram* & 254 & 67,19 \\
\hline Google & 28 & 7,40 \\
\hline Facebook & 23 & 6,08 \\
\hline Whatsapp & 22 & 5,82 \\
\hline Twitter & 19 & 5,02 \\
\hline Youtube & 11 & 2,91 \\
\hline Snapchat & 9 & 2,38 \\
\hline $\begin{array}{l}\text { Diğgr (Foursquare, Linkedin } \\
\text { Pinterest, Friendsfeed, Myspace) } \\
\text { Myspace* }\end{array}$ & 12 & 3,15 \\
\hline Toplam & & 0,26 \\
\hline
\end{tabular}

Lisans seviyesinde turizm eğitimi almakta olan öğrencilerin kullanma önceliğine göre sosyal medya araçları Tablo 2'de verilmiştir. Tabloya bakıldığında en fazla tercih edilen sosyal medya aracının açık ara Instagram $(\% 67,19)$ olduğu, en az tercih edilen aracın ise Myspace $(\% 0,26)$ olduğu görülmektedir. Açığa çıkn bu veriler Tablo 3'deki verilerle uyuşmaktadır. Böylece lisans seviyesinde turizm eğitimi almakta olan öğrenciler tarafından en sık kullanılan sosyal medya aracının Instagram olduğu, en az kullanılan sosyal medya aracının ise Myspace olduğu görülmektedir. 
Tablo 3. Öğrencilerin Sosyal Medya Araçlarını Kullanma Sıklığı

\begin{tabular}{|l|r|r|r|}
\hline Sosyal Medya Araci & \multicolumn{1}{|l|}{$\boldsymbol{N}$} & Ortalama & Standart Sapma \\
\hline Instagram & 478 & 4,25 & 1,074 \\
\hline Google+ & 476 & 3,52 & 1,387 \\
\hline Facebook & 484 & 2,53 & 1,192 \\
\hline Twitter & 477 & 2,37 & 1,377 \\
\hline Foursquare & 472 & 1,73 & 1,082 \\
\hline Pinterest & 473 & 1,68 & 1,125 \\
\hline Linkedin & 475 & 1,52 & 1,013 \\
\hline Firendfeed & 472 & 1,37 & 1,030 \\
\hline Myspace & 473 & 1,27 &, 731 \\
\hline
\end{tabular}

Lisans düzeyindeki turizm eğitimi alan öğrencilerin sosyal medya araçlarını kullanma sıklığı Tablo 3'te verilmiştir. Tabloya bakıldığında, sosyal medya araçlarından en fazla ortalamaya sahip olan aracın Instagram olduğu (4,2552), en az ortalamaya sahip olan aracın ise Myspace olduğu görülmektedir $(1,2770)$. Bu durum lisans seviyesinde turizm eğitimi almakta olan öğrencilerin en sık Instagram'ı kullandığını, en az ise Myspace'yi kullandığını göstermektedir. İçirgin (2018) de lisans düzeyinde eğitim alan öğrenciler üzerinde yaptığı çalışmasında katılımcların neredeyse tamamının Instagram'ı kullandığını saptamıştır. Bu durumun, lisans düzeyinde turizm eğitimi alan öğrencilerin en sık ve öncelikli olarak Instagram'ı kullandığını gösteren Tablo 2 ve Tablo 3'deki bulguları desteklediği söylenebilir.

Tablo 4, faktör analizi sonuçlarını göstermektedir. Bu tabloda lisans düzeyinde eğitim alan turizm öğrencilerinin sosyal medyayı kullanma amaçları ve alışkanlıklarının önemli bileşenleri olan eğlence, bilgi edinme, fayda sağlama, sosyalleşme ve sanallaştırma boyutlarının sonuçları açıklanmıştır. Bu boyutlardan ilki "eğlence" faktörüdür. Bu faktörde dört ifade bulunmakta ve toplam varyansın \%17,599'unu açıklamaktadır. Faktörü oluşturan ifadeler incelendiğinde en yüksek faktör yüküne sahip olan ifadenin "sosyal medyayı internette gezinmekten hoşlandığım için kullanırım" (,872) olduğu görülmektedir. Öte yandan "sosyal medyayı eğlenceli olduğu için kullanırım" $(, 867)$ önemli bir etkendir. Diğer önemli etkenler ise sırasiyla "sosyal medyayı zevkli olduğu için kullanırım" ve "sosyal medyayı zaman geçirmek için kullanırım" ifadeleri olmuştur. Bu bulgular lisans seviyesinde turizm eğitimi almakta olan öğrencilerin sosyal medyayı eğlenme amacıyla kullandıklarını göstermektedir. Şahin, Kaynakçı ve Aytop (2016) da yaptıkları çalışmalarında öğrencilerin sosyal medya kullanımlarındaki faktörlerden birini "eğlence" faktörü olarak bulmuştur. Bu durumda, çalışmada ortaya çıkan faktörlerden biri olan eğlence faktörünün doğrulandığı söylenebilir.

Bu faktörlerden ikinci faktöre "bilgi edinme" adı verilmiştir. Bu faktörde üç ifade bulunmakta ve toplam varyansın \%14,545'ini açıklamaktadır. Faktörü oluşturan ifadeler incelendiğinde en yüksek faktör yüküne sahip olan ifadenin "sosyal medyayı sektörel gelişmelere istediğim zamanda ulaşabildiğim için kullanırım" $(, 835)$ olduğu görülmektedir. Öte yandan "sosyal medyayı sektörel gelişmelere istediğim yerde ulaşabildiğim için kullanırım" $(, 798)$ önemli bir etkendir. Diğer önemli etken ise "sosyal medyayı kurumu ilgilendiren yenilikleri takip etmede kulanım kolaylığı sağladığı için kullanırım" $(, 716)$ ifadesi olmuştur. Bu bulgular lisans seviyesinde turizm eğitimi almakta olan öğrencilerin sosyal medyayı bilgi edinme amaciyla kullandıklarını göstermektedir. Balcı ve Ayhan'ın (2007) gerçekleştirdikleri çalışmalarında, lisans düzeyinde eğitim alan öğrencilerin sosyal medya kullanımına yönelik faktörlerden biri 
"bilgi edinme" faktörü olarak açığa çıkmıştır. Bu durumun, bu çalışmada açığa çıkan bilgi edinme boyutunu desteklediği iddia edilebilir.

Bu faktörlerden üçüncü faktöre "fayda sağlama" adı verilmiştir. Bu faktörde dört ifade bulunmakta ve toplam varyansın \%11,772'sini açıklamaktadır. Faktörü oluşturan ifadeler incelendiğinde en yüksek faktör yüküne sahip olan ifadenin "kişisel ilişkilerimde yeni kişiler tanımak için tek yol sosyal medyadır" $(, 836)$ olduğu görülmektedir. Öte yandan "sosyal medyayı yeni bilgiler elde etmek için kullanırım" $(, 684)$ önemli bir etkendir. Diğer önemli etkenler ise sırasıyla "sosyal medyayı faydalı şeyler öğrenmek için kullanırım" ve "sosyal medyanın kişisel gelişimime katkı sağladığını düşünüyorum" ifadeleri olmuştur. Bu bulgular lisans seviyesinde turizm eğitimi almakta olan öğrencilerin sosyal medyayı fayda sağlama amacıyla kullandıklarını göstermektedir. Balcı ve Ayhan'ın (2007) lisans düzeyinde üniversite öğrencilerinin sosyal medya kullanımlarıyla ilgili gerçekleştirdikleri çalışmalarında, lisans düzeyinde eğitim alan öğrencilerin sosyal medya kullanımına yönelik faktörlerden biri "bilgi edinme", Filiz, Erol, Dönmez ve Kurt (2014)'un çalışmalarında ise "eğitim amaçlı" olarak açığa çıkmıştır. Bu çalışmada açığa çıkan "fayda sağlama" boyutundaki ifadelerin her iki çalışmada açığa çıkn "bilgi edinme" ve "eğitim amaçlı" boyutlarındaki ifadeleri de kapsadığı görülmektedir. Dolayısıyla öğrenciler için fayda sağlayıcı olduğu düşünülen bu boyutların çalışmada açığa çıkan "fayda sağlama" boyutunu desteklediği söylenebilir.

$\mathrm{Bu}$ faktörlerden dördüncü faktöre "sosyalleşme" adı verilmiştir. Bu faktörde üç ifade bulunmakta ve toplam varyansın \%11,609'unu açıklamaktadır. Faktörü oluşturan ifadeler incelendiğinde en yüksek faktör yüküne sahip olan ifadenin "sosyal medyayı sektörel gelişmelere istediğim zamanda ulaşabildiğim için kullanırım" $(, 835)$ olduğu görülmektedir. Öte yandan "sosyal medyayı kendimi özgürce ifade etmek için kullanırım" (,719) önemli bir etkendir. Diğer önemli etken ise "başka insanların hayatı ile ilgilenir, sosyal medyayı takip için kullanırım" (,714) ifadesi olmuştur. Bu bulgular lisans seviyesinde turizm eğitimi almakta olan öğrencilerin sosyal medyayı kullanarak sosyalleştiklerini göstermektedir. Filiz ve diğerlerinin (2014) bir üniversitenin lisans düzeyinde eğitim veren fakültesinde gerçekleştirdikleri çalışmalarında öğrencilerin sosyal medya kullanma amacı ve alışkanlıklarıyla ilgili açığa çıkardıkları faktörlerden biri "sosyal etkileşim ve iletişim" olarak adlandırılmıştır. Dolayısıyla ortaya çıkan bu bulgu, çalışmada açığa çıkan "sosyalleşme" boyutuyla örtüşmektedir. Böylece lisans düzeyinde eğitim alan öğrencilerin sosyal medyayı farklı fakültelerde olsalar dahi sosyalleşme amacıyla da kullandıkları iddia edilebilir.

Bu faktörlerden beşinci faktöre "sanallaştırma" adı verilmiştir. Bu faktörde dört ifade bulunmakta ve toplam varyansın \%11,122'sini açıklamaktadır. Faktörü oluşturan ifadeler incelendiğinde en yüksek faktör yüküne sahip olan ifadenin "sosyal medyada paylaşımların güvenilir olmadığını düşünüyorum" (,764) ifadesinin olduğu görülmektedir. Öte yandan "sosyal medyada insanların gerçek kişiliklerinden farklı davrandığını düşünüyorum" (,704) ifadesi önemli bir etkendir. Diğer önemli etkenler ise sırasıyla "sosyal medyanın zaman israfına neden olduğunu düşünüyorum" ve "sosyal medyanın arkadaşlar arasında fiziki birlikteliği azalttığını düşünüyorum" ifadeleri olmuştur. Bu bulgular lisans seviyesinde turizm eğitimi almakta olan öğrencilerin sosyal medyada olduklarından farklı kişiliklere büründüklerini ve yapmacıklaştıklarını göstermektedir. Yapılan bazı çalışmalarda (Argın, 2013; Çetinkaya, 2013; Gürültü, 2016) da sosyal medyanın üniversite öğrencileri üzerinde bağımlılık etkisi yarattığına ve böylece gerçek dünyadan koparak sanallaştıkları tespit edilmiştir. Yapılan çalışmalardaki bulgular, bu çalışmada öğrencilerin sosyal medya kullanım amaçları ve alışkanlıklarında sanallaşma faktörünün ortaya çıkmasını doğrulayabilmektedir. 
Tablo 4. Açıklayıcı Faktör Analizine İlişkin Bulgular

\begin{tabular}{|c|c|c|c|}
\hline \multicolumn{4}{|l|}{ İfadeler } \\
\hline Ĕglence & Eş Kökenlilik & Yük & \\
\hline $\begin{array}{l}\text { Sosyal medyayı internette gezinmekten } \\
\text { hoşlandığım için kullanırım. }\end{array}$ & ,769 &, 872 & \multirow{4}{*}{$\begin{array}{l}\text { Öz değer: } 3,027 \\
\text { Varyans: \%17,599 } \\
\text { Ortalama: 3,6874 } \\
\text { Güvenilirlik: ,892 } \\
P \text { değeri: ,000 }\end{array}$} \\
\hline Sosyal medyayı eğlenceli olduğu için kullanırım. & ,811 &, 867 & \\
\hline Sosyal medyayı zevkli olduğu için kullanırım. & ,755 & 836 & \\
\hline Sosyal medyayı zaman geçirmek için kullanırım. & ,692 &, 832 & \\
\hline \multicolumn{4}{|l|}{ Bilgi Edinme } \\
\hline $\begin{array}{l}\text { Sosyal medyayı sektörel gelişmelere istediğim } \\
\text { zamanda ulaşabildiğim için kullanırım. }\end{array}$ & ,734 & ,835 & \multirow{3}{*}{$\begin{array}{l}\text { Öz değer: 2,090 } \\
\text { Varyans: \%14,545 } \\
\text { Ortalama: 3,4942 } \\
\text { Güvenilirlik: ,781 } \\
\text { P değeri: ,000 }\end{array}$} \\
\hline $\begin{array}{l}\text { Sosyal medyayı sektörel gelişmelere istediğim } \\
\text { yerde ulaşabildiğim için kullanırım. }\end{array}$ & ,735 & ,798 & \\
\hline $\begin{array}{l}\text { Sosyal medyayı kurumu ilgilendiren yenilikleri } \\
\text { takip etmede kulanım kolaylığı sağladığ } ı \text { için } \\
\text { kullanırım. }\end{array}$ & 621 & ,716 & \\
\hline \multicolumn{4}{|l|}{ Fayda Sağlama } \\
\hline $\begin{array}{l}\text { Sosyal medyayı araştırma yapmada iyi bir } \\
\text { yöntem olduğu için kullanırım. }\end{array}$ & ,787 & ,687 & \multirow{4}{*}{$\begin{array}{l}\text { Öz değer: } 2,529 \\
\text { Varyans: \%11,772 } \\
\text { Ortalama: 3,5514 } \\
\text { Güvenilirlik: ,786 } \\
\text { P değeri: ,000 }\end{array}$} \\
\hline $\begin{array}{l}\text { Sosyal medyay yeni bilgiler elde etmek için } \\
\text { kullanırım. }\end{array}$ & ,769 &, 684 & \\
\hline $\begin{array}{l}\text { Sosyal medyayı faydalı şeyler ö̆grenmek için } \\
\text { kullantrım. }\end{array}$ & 770 & ,665 & \\
\hline $\begin{array}{l}\text { Sosyal medyanın kişisel gelişimime katkı } \\
\text { sağladığıı düşünüyorum. }\end{array}$ & 202 & ,616 & \\
\hline \multicolumn{4}{|l|}{ Sosyalleşme } \\
\hline $\begin{array}{l}\text { Kişisel ilişkilerimde yeni kişiler tanımak için tek } \\
\text { yol sosyal medyadır. }\end{array}$ & ,640 &, 836 & \multirow{3}{*}{$\begin{array}{l}\text { Öz değer: 1,906 } \\
\text { Varyans: \%11,609 } \\
\text { Ortalama: 2,7469 } \\
\text { Güvenilirlik: ,713 } \\
\text { P değeri: ,000 }\end{array}$} \\
\hline $\begin{array}{l}\text { Sosyal medyayı kendimi özgürce ifade etmek için } \\
\text { kullanırım. }\end{array}$ & ,638 & ,719 & \\
\hline $\begin{array}{l}\text { Başka insanların hayatı ile ilgilenir, sosyal } \\
\text { medyayı takip için kullanırım. }\end{array}$ & ,628 & ,714 & \\
\hline \multicolumn{4}{|l|}{ Sanallaştırma } \\
\hline $\begin{array}{l}\text { Sosyal medyada paylaşımların güvenilir } \\
\text { olmadığııı düşünüyorum. }\end{array}$ &, 576 & ,764 & \multirow{4}{*}{$\begin{array}{l}\text { Öz değer: } 1,974 \\
\text { Varyans: } \% 11,122 \\
\text { Ortalama: 3,5237 } \\
\text { Güvenilirlik: ,650 } \\
\text { P değeri: ,000 }\end{array}$} \\
\hline $\begin{array}{l}\text { Sosyal medyada insanların gerçek kişiliklerinden } \\
\text { farklı davrandığını düşünüyorum. }\end{array}$ &, 538 & 704 & \\
\hline $\begin{array}{l}\text { Sosyal medyanın zaman israfina neden olduğunu } \\
\text { düşünüyorum. }\end{array}$ & 396 &, 663 & \\
\hline $\begin{array}{l}\text { Sosyal medyanın arkadaşlar arasında fiziki } \\
\text { birlikteliği azalttığını düşünüyorum. }\end{array}$ & 463 & 653 & \\
\hline \multicolumn{4}{|c|}{$\begin{array}{l}\text { Varimax rotasyonlu temel bileşenler analizi. Açılanan toplam varyans: \%66,646 } \\
\text { Kaiser-Meyer-Olkin Örneklem yeterliliği: \%81,6; Barlett küresellik testi: X²: 3520,077 s.d.:153, } \\
\text { p<0,001 }\end{array}$} \\
\hline
\end{tabular}


Çalışmada lisans seviyesinde turizm eğitimi almakta olan öğrencilerin sosyal medyayı kullanma amaçları ve alışkanlıklarının öğrencilerin betimleyici özelliklerine göre farklılık gösterip göstermedikleri incelenmiştir. Öğrencilerin cinsiyetlerine göre farklılıklarının analiz edilmesi için oluşturulan hipotez aşağıdaki gibidir.

$\mathrm{H}_{1}$ : Öğrencilerin sosyal medyayı kullanma amaçları ve alışkanlıkları cinsiyetlerine göre farklılık göstermektedir.

Yapılan t-testi neticesinde lisans seviyesinde turizm eğitimi almakta olan öğrencilerin sosyal medyayı kullanma amaçları ve alışkanlıklarının hiçbir boyutta cinsiyetlerine göre farklılık göstermediği tespit edilmiştir. Dolayısıyla $\mathrm{H}_{1}$ hipotezi reddedilmiştir. Bu durum, turizm eğitimi almakta olan lisans öğrencilerinin cinsiyetlerine göre aynı düzeyde sosyal medyayı kullandıkları söylenebilir. Aydın ve Çelik (2017) de gerçekleştirdikleri çalışmalarında da lisans öğrencilerinin sosyal medya kullanımlarının cinsiyetlerine göre farklılık göstermediğini, her iki cinsiyet grubunun da sosyal medyayı benzer şekilde kullandıklarını tespit etmiştir. Aydın ve Çelik gibi Çakır (2018) da farklı bir lisans düzeyinde turizm eğitimi veren bir fakültede gerçekleştirdiği çalışmasında öğrencilerin sosyal medyayı kullanımlarında cinsiyete göre bir farklılık olmadığını saptamıştır. Her iki çalışmadan ortaya çıkan bulguların da $\mathrm{H}_{1}$ hipotezini doğrular nitelikte olduğu söylenebilir. Öğrencilerin uyruklarına göre sosyal medyayı kullanma amaçları ve alışkanlıklarının farklılıklarını analiz etmek için oluşturulan hipotez ise aşağıdaki gibidir.

$\mathrm{H}_{2}$ : Öğrencilerin sosyal medyayı kullanma amaçları ve alışkanlıkları uyruklarına göre farklılık göstermektedir.

Lisans seviyesinde turizm eğitimi almakta olan öğrencilerin sosyal medyayı kullanma amaçları ve alışkanlıklarının sadece fayda sağlama boyutunda uyruklarına göre farklılık $\mathrm{t}$ testi ile analiz edilmiştir. Analize ilişkin bulgular Tablo 5'te yer almaktadır.

Tablo 5. Öğrencilerin Uyruklarına Göre Sosyal Medyayı Kullanma Amaçları ve Alışkanlıklarına Yönelik T-Testi Sonuçları

\begin{tabular}{|l|l|l|l|l|l|l|}
\hline & Uyruk & $\mathbf{N}$ & $\overline{\bar{X}}$ & Standart Sapma & Standart Hata & \multirow{2}{*}{ Sig. } \\
\hline \multirow{2}{*}{ Fayda Sağlama } & Yerli & 466 & 3,5247 &, 86334 &, 03999 & \multirow{2}{*}{001} \\
\cline { 2 - 8 } & Yabancl & 20 & 4,1750 &, 69821 &, 15612 & \\
\hline
\end{tabular}

Tablo 5'e göre; lisans seviyesinde turizm eğitimi almakta olan öğrencilerin sosyal medyayı kullanma amaçları ve alışkanlıklarının yalnızca fayda sağlama boyutunda uyruklara göre farklılık göstermesi nedeniyle bu hipotez kısmen kabul edilmiştir. Buna göre; yabancı öğrencilerin yerli öğrencilere göre sosyal medyayı daha fazla fayda sağlama amaçlı kullandıkları görülmektedir $(=4,17)$. Bu durumda yerli öğrencilerin sosyal medyayı fayda sağlama amacıyla kullanmaya yönlendirmek amacıyla birtakım çalışmaların yapılması, sosyal medyayı daha etkin kullanabilmeleri açısından önerilebilir. Günay, Öztürk, Ergün Arslantaş ve Sevinç (2018) de, gerçekleştirdikleri çalışmalarında lisans düzeyinde eğitim alan yerli öğrencilerin sosyal medyaya bağımlı oldukları için sosyal medyadan gerekli faydayı sağlayamadıklarına değinmiştir. Böylece çalışmadaki $\mathrm{H}_{2}$ hipotezinin desteklendiği söylenebilir. Öğrencilerin bölümlerine göre sosyal medyayı kullanma amaçları ve alışkanlıklarının farklılıklarını analiz etmek için oluşturulan hipotez ise aşağıdaki gibidir. 
$\mathrm{H}_{3}$ : Öğrencilerin sosyal medyayı kullanma amaçları ve alışkanlıkları okudukları bölümlere göre farklılık göstermektedir.

Lisans seviyesinde turizm eğitimi almakta olan öğrencilerin sosyal medyayı kullanma amaçları ve alışkanlıklarının sadece fayda sağlama boyutunda okudukları bölümlere göre farklılık t-testi ile analiz edilmiştir. Analize ilişkin bulgular Tablo 6'da yer almaktadır.

Tablo 6. Lisans Seviyesinde Turizm Eğitimi Almakta Olan Öğrencilerin Bölümlerine Göre Sosyal Medyayı Kullanma Amaçları ve Alışkanlıklarına Yönelik T-Testi Sonuçları

\begin{tabular}{|c|c|c|c|c|c|c|}
\hline & Bölüm & $N$ & $\bar{X}$ & $\begin{array}{l}\text { Standart } \\
\text { Sapma }\end{array}$ & $\begin{array}{l}\text { Standart } \\
\text { Hata }\end{array}$ & Sig. \\
\hline \multirow{2}{*}{$\begin{array}{l}\text { Fayda } \\
\text { Sağlama }\end{array}$} & Turizm İşletmeciliği & 141 & 3,7447 &, 81748 &, 06884 & \multirow[b]{2}{*}{011} \\
\hline & $\begin{array}{l}\text { Seyahat İşletmeciliŭi ve } \\
\text { Turizm Rehberliği }\end{array}$ & 73 & 3,4315 & ,91407 & 10698 & \\
\hline
\end{tabular}

Yapılan t-testi neticesinde lisans seviyesinde turizm eğitimi almakta olan öğrencilerin sosyal medyayı kullanma amaçları ve alışkanlıklarının sadece fayda sağlama boyutunda okudukları bölümlere göre farklılık gösterdiği tespit edilmiştir. Dolayısıyla elde edilen bulgular doğrultusunda; lisans seviyesinde turizm eğitimi almakta olan öğrencilerin sosyal medyayı kullanma amaçları ve alışkanlıklarının yalnızca fayda sağlama boyutunda öğrenim görülen bölümlere göre farklılık göstermesi nedeniyle bu hipotez kısmen kabul edilmiştir. Buna göre; Turizm İşletmeciliği bölümü öğrencilerinin Seyahat İşletmeciliği ve Turizm Rehberliği bölümü öğrencilerine göre sosyal medyayı daha fazla fayda sağlama amaçlı kullandıkları görülmektedir $(=3,74)$. Çakmak (2014) da gerçekleştirdiği çalışmasında lisans düzeyinde eğitim alan öğrencilerin sosyal medya kullanımlarının bölümlere göre farklılık gösterdiğini tespit etmiştir. Çakmak'ın çalışmasında ortaya çıkan bu bulgunun, çalışmadaki $\mathrm{H}_{3}$ hipotezini desteklediği söylenebilir. Öğrencilerin sınıflarına göre sosyal medyayı kullanma amaçları ve alışkanlıklarının farklılıklarını analiz etmek için oluşturulan hipotez ise aşağıdaki gibidir.

$\mathrm{H}_{4}$ : Lisans seviyesinde turizm eğitimi almakta olan öğrencilerin sosyal medyayı kullanma amaçları ve alışkanlıkları hangi sınıfta okuduklarına göre farklılık göstermektedir.

Lisans seviyesinde turizm eğitimi almakta olan öğrencilerin sosyal medyayı kullanma amaçları ve alışkanlıklarının sadece fayda sağlama boyutunda okudukları sınıflara göre farklılık gösterip göstermediği ANOVA testi ile analiz edilmiştir. Analize ilişkin bulgular Tablo 7'de yer almaktadır.

Öncelikle ANOVA testi yapmadan önce ifadelere Levene testi yapılmıştır. Levene testi sonucunda varyansların homojen dağılım gösterdikleri tespit edilmiştir $(\mathrm{p}=, 712<, 005)$. Yapılan ANOVA testi neticesinde lisans seviyesinde turizm eğitimi almakta olan öğrencilerin sosyal medyayı kullanma amaçları ve alışkanlıklarının sadece sosyalleşme boyutunda okudukları sınıfa göre farklılık gösterdiği tespit edilmiştir. Dolayısıyla elde edilen bulgular doğrultusunda; lisans seviyesinde turizm eğitimi almakta olan öğrencilerin sosyal medyayı kullanma amaçları ve alışkanlıklarının yalnızca sosyalleşme boyutunda öğrenim aşamalarına göre farklılık göstermesi nedeniyle bu hipotez kısmen kabul edilmiştir. Buna göre; birinci sınıf öğrencilerinin diğer sınıflarda okuyan öğrencilere göre sosyal medyayı daha fazla sosyalleşme amaçlı 
kullandıkları görülmektedir $(=2,91)$. Bu durum, öğrencilerin okulda yeni oldukları için sosyal medya vasıtasıyla yeni arkadaş edinmeye eğilim gösterdikleri şeklinde açıklanabilir. Eryılmaz (2018) da farklı bir turizm fakültesi öğrencileriyle gerçekleştirdiği çalışmasında lisans düzeyinde turizm eğitimi alan öğrencilerin sosyal medyayı kullanımlarının okudukları sınıflara göre farklılık gösterdiğini tespit etmiştir. Literatürdeki bazı çalışmalarda da (Valenzuela, Park ve Kee, 2009; Christofides, Muise ve Desmarais, 2009; Berthon, Pitt ve Desautels, 2011) özellikle gençlerin sosyal medyayı sosyalleşme amacıyla kullandığına değinilmiştir. Bu çalışmada lisans düzeyinde turizm eğitimi alan birinci sınıfların diğer sınıflara göre daha fazla sosyalleşme amacıyla kullanmaları da bu durumu teyit edebilir. Öğrencilerin sosyal medyada elde ettiği faydada eğlence, bilgi edinme ve sosyalleşmenin etkili olup olmadığını ölçen hipotez ise aşağıda yer almaktadır.

Tablo 7. Lisans Seviyesinde Turizm Eğitimi Almakta Olan Öğrencilerin Öğrenim Aşamalarına Göre Sosyal Medyayı Kullanma Amaçları ve Alışkanlıklarına Yönelik ANOVA Testi Sonuçları

\begin{tabular}{|c|c|c|c|c|c|c|c|}
\hline & Sinıf & $N$ & $\bar{x}$ & Standart Sapma & Standart Hata & $F$ & Sig. \\
\hline \multirow{4}{*}{ Sosyalleşme } & 1. Sinif & 136 & 2,9191 & 1,06226 & ,9109 & \multirow[t]{4}{*}{2,662} & \multirow{4}{*}{,047 } \\
\hline & 2. Sinif & 117 & 2,8148 & 1,08317 & ,10014 & & \\
\hline & 3. Sinif & 133 & 2,6165 & 1,05608 & 09157 & & \\
\hline & 4. Sinif & 100 & 2,6067 & 98174 & 09857 & & \\
\hline
\end{tabular}

$\mathrm{H}_{5}$ : Lisans seviyesinde turizm eğitimi almakta olan öğrencilerin sosyal medyada elde ettiği faydada eğlence, bilgi edinme ve sosyalleşme etkilidir.

Lisans seviyesinde turizm eğitimi almakta olan öğrencilerin sosyal medyada elde ettiği faydada eğlence, bilgi edinme ve sosyalleşmenin etkili olup olmadığı regresyon analizi yapılarak test edilmiştir. Analize ilişkin bulgular Tablo 8'de yer almaktadır.

Tablo 8. Lisans Seviyesinde Turizm Eğitimi Almakta Olan Öğrencilerin Sosyal Medyadan Sağladıkları Faydaya İlişkin Regresyon Analizi Sonuçları

\begin{tabular}{|c|c|c|c|c|}
\hline \multirow[b]{2}{*}{ Model } & \multicolumn{2}{|c|}{$\begin{array}{c}\text { Standardize Edilmemiş } \\
\text { Katsayılar }\end{array}$} & \multirow{2}{*}{$\begin{array}{r}\begin{array}{r}\text { Standardize } \\
\text { Katsayılar }\end{array} \\
\beta \\
\end{array}$} & \multirow[t]{2}{*}{ t-değeri } \\
\hline & B & Std. Hata & & \\
\hline Fayda sağlama & 1,205 & ,161 & & 7,494 \\
\hline Eğlence & 157 & ,033 & , 186 & 4,817 \\
\hline Bilgi edinme & 490 & 036 & ,519 & $\begin{array}{c}13,73 \\
8\end{array}$ \\
\hline Sosyalleşme & ,020 & ,031 & ,025 & 652 \\
\hline \multicolumn{5}{|c|}{$\begin{array}{c}\text { Sağlama; Metot: Doğrudan, } R=, 593, R^{2}= \\
\% 35,2, \text { Düzeltilmiş } R^{2}=\% 34,8 ; \text { Model için } \\
\text { F:87,303; } p<0,001\end{array}$} \\
\hline
\end{tabular}


Tablo 8'e göre; regresyon modelinin genel anlamlılığının sınandı̆̆ $F$ değeri 87,303 olarak hesaplanmıştır. F: 87,303 ve p<0,001 olduğundan genel regresyon modeli anlamlıdır. Regresyon modelinde "eğlence" boyutunun sosyal medyadan fayda sağlama üzerinde anlamlı bir etkisi olduğu tespit edilmiştir. Buna göre "eğlence" boyutunda meydana gelen bir birimlik artış sosyal medyadan fayda sağlamayı ,186 birim arttırmaktadır. Regresyon modelinde "bilgi edinme" boyutunun da sosyal medyadan fayda sağlama üzerinde anlamlı bir etkisi olduğu tespit edilmiştir. Buna göre "bilgi edinme" boyutunda meydana gelen bir birimlik artış sosyal medyadan fayda sağlamayı, 519 birim arttırmaktadır. Uygulanan regresyon analizi sonucunda $\mathrm{H}_{5}$ hipotezi araştırma bulgularınca kısmen kabul edilmiştir. Böylece eğlence, bilgi edinme ve sosyalleşmenin sosyal medyadan fayda sağlama üzerinde etki sağlayabileceği anlaşılmaktadır. Eğlence, bilgi edinme ve sosyalleşmedeki artışa bakılarak sosyal medyada fayda sağlamanın da artacağı söylenebilir. Çalışmadaki bu bulguya paralel olarak Baz (2018), gerçekleştirdiği çalışmasında öğrencilerin sosyal medyayı kullanırken eğlenme fırsatı bulduklarını ve eğlenirken aynı zamanda bilgi edinebildiğine değinmiştir. Dolayısıyla öğrencilerin sosyal medya sayesinde kendileri için birtakım faydalar sağladıkları iddia edilebilir.

\section{SONUÇ VE ÖNERİLER}

Günümüzde sosyal medyanın neredeyse herkes tarafından kullanıldığı görülmektedir. Alanyazında sosyal medyanın özellikle $\mathrm{Y}$ ve $\mathrm{Z}$ kuşakları için kendilerini kolay bir şekilde ifade etmelerini sağlayan yeni sosyalleşme alanları olduğuna değinilmiştir (Valkenburg, Peter ve Schouten, 2006; Ellison, Steinfeld ve Lampe, 2007; Valenzuela vd., 2009; Christofides vd., 2009; Berthon vd., 2011). Teknolojiyle iç içe büyüme fırsatı bulan bu kuşakların oluşturduğu lisans seviyesinde turizm eğitimi almakta olan öğrenciler için de bu durum geçerlidir. Bu çalışmada lisans seviyesinde turizm eğitimi almakta olan öğrencilerin sosyal medyayı kullanma amaçları ve alışkanlıkları incelemeye alınmıştır.

Lisans seviyesinde turizm eğitimi almakta olan öğrencilerin en sık Instagram'ı kullandıkları ve sosyal medya kanalları arasında öncelikli olarak Instagram'ı tercih ettikleri tespit edilmiştir. Bedir (2016), çalışmasında önlisans ve lisans düzeyinde eğitim alan öğrencilerin en çok Facebook'u kullandıkları bulgusuna ulaşmıştır. Bu çalışmada lisans seviyesinde turizm eğitimi almakta olan öğrencilerin tercihlerinde Instagram'ın diğer sosyal medya araçlarına göre daha çok kullanılması, son yıllarda Instagram'ın getirdiği çeşitli yeniliklerle açıklanabilir.

Çalışmada elde edilen bulgulara göre; lisans seviyesinde turizm eğitimi almakta olan öğrencilerin sosyal medyayı kullanma amaçları ve alışkanlıklarının beş boyuttan oluştuğu tespit edilmiştir. Bu boyutlardan en fazla faktör yüküne sahip olan boyutun eğlence boyutu olduğu tespit edilmiştir. $\mathrm{Bu}$ durum öğrencilerin sosyal medyayı en çok eğlenme amaciyla kullandıklarını göstermektedir. Literatüre bakıldığında Vural ve Bat (2010)'ın gerçekleştirdikleri çalışmada bu sonuca benzer bir şekilde sosyal medyanın üniversite öğrencileri için önemli bir eğlence kaynağı olduğu görülmektedir.

Çalışmada ayrıca lisans seviyesinde turizm eğitimi almakta olan öğrencilerin sosyal medyayı kullanma amaçları ve alışkanlıklarının sırasıyla cinsiyetlerine, uyruklarına, bölümlerine ve hangi sinıfta öğrenim gördüklerine göre farklılık gösterip göstermediği incelenmiştir. Öğrencilerin sosyal medyayı kullanma amaçları ve alışkanlıklarının hiçbir boyutta cinsiyetlerine göre farklılık göstermediği tespit edilmiştir. Bu da bize hem kadın hem de erkek öğrencilerin sosyal medyayı aynı doğrultuda kullandığını göstermektedir. Literatüre bakıldığında Aydın ve Çelik (2017)'in gerçekleştirdikleri çalışmalarında bu sonuca paralel bir şekilde sosyal medya algılamalarının öğrencilerin cinsiyetlerine göre farklılık göstermediğini tespit ettikleri 
görülmektedir. Yazarlar çalışmalarında sosyal medyanın her iki cinsiyet grubu için de benzer şekilde algılandığına değinmişlerdir.

Çalışmada öğrencilerin sosyal medyayı kullanma amaçları ve alışkanlıklarının yerli veya yabancı olmalarına göre ve bölümlerine göre sadece bilgi edinme boyutunda farklılık gösterdiği tespit edilmiştir. Ayrıca öğrencilerin sosyal medyayı kullanma amaçları ve alışkanlıklarının öğrenim aşamalarına göre sadece sosyalleşme boyutunda farklılık gösterdiği tespit edilmiştir. Buna göre birinci sınıf öğrencilerinin üst sınıflara göre sosyal medyayı daha çok sosyalleşme amacıyla kullandığı saptanmıştır. Alanyazındaki bazı çalışmalarda da buna benzer sonuçlara ulaşılmıştır. Bolton ve diğerleri (2013), yaptıkları çalışmalarında Y kuşağının üst kuşaklara göre sosyal medya uygulamaları aracılığıyla daha fazla sosyalleştiğini saptamıştır. Sütlüoğlu (2015) ise, gerçekleştirdiği çalışmada Z kuşağındaki öğrencilerin Facebook arkadaşlarının daha büyük yaştaki öğrencilere göre daha fazla olduğunu tespit etmiştir. Bu durum, birinci sinıfa yeni başlayan öğrencilerin yeni bir çevreye girmeleri ve arkadaş sayılarının kısıtlı olması nedeniyle sosyal medyayı yeni arkadaş edinme amaçlı kullanmalarıyla açıklanabilir.

Çalışmada lisans seviyesinde turizm eğitimi almakta olan öğrencilerin sosyal medyada elde ettikleri fayda üzerinde eğlenme ve bilgi edinmenin etkili olduğu tespit edilmiştir. Bu durum, öğrencilerin sosyal medya vasıtasıyla birçok fayda elde ettiklerini gösterebilmektedir. Bu faydaların açı̆̆a çıkmasında, öğrencilerin sosyal medya kullanırlarken eğlenceli vakit geçirebilmeleri ve merak ettikleri konular hakkında bilgi edinebilmelerinin etkili olduğu söylenebilir. Baz (2018) da gerçekleştirdiği çalışmasında, öğrencilerin sosyal medyada eğlenceli vakit geçirme fırsatı bulduklarını ve merak ettikleri birtakım konularda sosyal medya kanalları vasıtasıyla bilgi edinebildiklerine değinmiştir.

Tüm bu sonuçlar doğrultusunda lisans seviyesinde turizm eğitimi almakta olan öğrencilerin sosyal medyayı kullanma amaçları ve alışkanlıklarının çeşitli özelliklerine göre farklılık gösterdiği görülmüştür. Bu sonuçlardan yola çıkılarak lisans seviyesinde turizm eğitimi almakta olan öğrencilerin sosyal medya uygulamalarına ilgilerinin üst düzey olduğu söylenebilir. Dolayısıyla özellikle $Y$ ve $Z$ kuşaklarının öğrenim gördüğü eğitim kurumlarında sosyal medyaya daha fazla değinilerek öğrencilerin dikkatleri anlatılan konular üzerine yoğunlaştırılabilir. Ayrıca bundan sonra yapılacak olan çalışmalarda turizm fakültesi öğrencilerinin dışında, diğer fakültelerin öğrencilerinin de sosyal medyayı kullanma amaçları ve alışkanlıkları incelenerek, birbirleriyle karşılaştırılabilir.

Çalışmada öğrencilerin sosyal medya platformları arasından açık ara en çok Instagram'ı tercih ettiği tespit edilmiştir. Dolayısıyla lisans düzeyinde turizm dersleri verilirken yeri geldikçe Instagram'daki paylaşımlardan da faydalanılması öğrencilerin dikkatini toplama açısından fayda sağlayabilir. Çalışmada lisans düzeyinde turizm eğitimi almakta olan öğrencilerin sosyal medyayı kullanırken eğlenme fırsatı buldukları, bilgi edinebildikleri, kendileri için birtakım faydalar sağladıkları, sosyalleştikleri saptanmıştır. Dolayısıyla fakültelerde ders verilirken sosyal medyadan faydalanılması öğrenciler için dersleri daha keyifli bir hale getirebilir. Ayrıca öğrencilerin sosyal medyadan fayda sağlamasında eğlence ve bilgi edinme boyutlarının etkili olduğunun tespit edilmesi tüm bu önerileri doğrular niteliktedir.

\section{KAYNAKÇA}

Argın, S. F. (2013). Ortaokul ve Lise Öğrencilerinin Sosyal Medyaya İlişkin Tutumlarının İncelenmesi (Çekmeköy Örneği). Yayımlanmamış Yüksek Lisans Tezi, Yeditepe Üniversitesi Sosyal Bilimler Enstitüsü, İstanbul. 
Atılgan, D. (2006). İletişim Teknolojileri Çağında Değişen Bilgi Hizmetleri, 1. Uluslararası Bilgi Hizmetleri Sempozyumu: İletişim, içinde, İstanbul 25-26 Mayıs 2006, İstanbul.

Aydın, M., ve Çelik, T. (2017). Sosyal Bilgiler Öğretmen Adaylarının Sosyal Medya Kullanım ve Doyumlarının İncelenmesi, Eğitim Kuram ve Uygulama Araştırmaları Dergisi, 3(2): 82-97.

Aziz, A. (2008). İletişime Giriş. İstanbul: Aksu Kitapevi.

Balcı, Ş., ve Ayhan, B. (2007). Üniversite Öğrencilerinin İnternet Kullanım ve Doyumları Üzerine Bir Saha Araştırması, Selçuk Üniversitesi İletişim Fakültesi Dergisi, 5(1): 174-197.

Baz, F. Ç. (2018). Sosyal Medya Bağımlılığı: Üniversite Öğrencileri Üzerine Çalışma, Uluslararası Toplum Araştırmaları Dergisi, 9(16): 278-295.

Bedir, A. (2016). Sosyal Medya Kullanımının Üniversite Öğrencilerinin Akademik Başarılarına ve Tutumlarına Etkisi, Yayınlanmamış Yüksek Lisans Tezi, Atatürk Üniversitesi Eğitim Bilimleri Enstitüsü, Erzurum.

Berthon, P., Pitt, L. and Desautels, P. (2011). Unveiling Videos: Consumer-Generated Ads as Qualitative İnquiry, Psychology and Marketing, 28(10): 1044-1060.

Bolton, R. N., Parasuraman, A., Hoefnagels, A., Migchels, N., Kabadayi, S., Gruber, T., Loureiro, Y. K., and Solnet, D. (2013). Understanding Generation Y and Their Use of Social Media: A Review and Research Agenda, Journal of Service Management, 24(3): 245-267.

Chakraborty, R., Vishik, C., and Rao, H. R. (2013). Privacy Preserving Actions of Older Adults on Social Media: Exploring the Behavior of Opting out of Information Sharing, Decision Support Systems, 55: 948-956.

Christofides, E., Muise, A., and Desmarais, S. (2009). Information Disclosure and Control on Facebook: Are They Two Sides of The Same Coin or Different Processes?, Cyber Psychology and Behavior, 12(3): 341-345.

Çakır, H. (2018). Kırgızistan-Türkiye Manas Üniversitesi Öğrencilerinin Sosyal Medya Kullanım Alışkanlıkları, Manas Sosyal Araştırmalar Dergisi, 7(3): 539-563.

Çakmak, V. (2014). İletişim Kaygısının Sosyal Medya Kullanımı Üzerine Olan Etkisi: Üniversite Öğrencileri Üzerine Örnek Olay İncelemesi, Yayınlanmamış Doktora Tezi, Selçuk Üniversitesi Sosyal Bilimler Enstitüsü Halkla İlişkiler ve Tanıtım Anabilim Dalı Halkla İlişkiler Bilim Dalı, Konya.

Çetinkaya, M. (2013). Illköğretim Öğrencilerinde İnternet Bağımlılığının İncelenmesi, Yayımlanmamış Yüksek Lisans Tezi, Dokuz Eylül Üniversitesi Eğitim Bilimleri Enstitüsü, İzmir.

Dickey, I. J., Lewis, W. F. and Siemens, J. C. (2008). The Evolution of Internet Weblogs: History, Current Trends and Usage in Marketing Strategy, Journal of Business and Behavioral Sciences, 19(1): 91-102.

Ellison, N. B., Steinfeld, C. and Lampe, C. (2007). The Benefits of Facebook 'Friends': Social Capital and Students' Use of Online Social Network Sites, Journal of Computer-Mediated Communication, 12(4): 1143-1168.

Eröz, S. S. ve Doğdubay, M. (2012). Turistik Ürün Çeşitlerinde Sosyal Medyanın Rolü ve Etik İlişkisi, Dokuz Eylül Üniversitesi İktisadi ve İdari Bilimler Fakültesi Dergisi, 27(1): 133-157.

Eryılmaz, S. (2018). Öğrencilerin Bilgi ve İletişim Teknolojileri Yeterliliklerinin Belirlenmesi: Gazi Üniversitesi, Turizm Fakültesi Örneği, Elektronik Sosyal Bilimler Dergisi, 17(65): 37-49. 
Filiz, O., Erol, O., Dönmez, F. İ., ve Kurt, A. A. (2014). BÖTE Bölümü Öğrencilerinin Sosyal A $\breve{g}$ Siteleri Kullanım Amaçları ile İnternet Bağımlılıkları Arasındaki İlişkinin İncelenmesi, Journal of Instructional Technologies \& Teacher Education, 3(2): 17-28.

Goetsch, D. L. (1984). Impact of Technology on Curriculum and Delivery Strategies in Vocational Education, (Editör) Shulman, C. H.: Adults and the Changing Workplace in (p.191-200), USA: American Vocational Association.

Günay, O., Öztürk A., Ergün Arslantaş, E. and Sevinç N. (2018). Internet Addiction and Depression Levels in Erciyes University Students, Düşünen Adam The Journal of Psychiatry and Neurological Sciences, 31: 79-88.

Gürültü, E. (2016). Lise Öğrencilerinin Sosyal Medya Bağımlllıları ve Akademik Erteleme Davranışları Arasındaki İlişkinin İncelenmesi, Yayınlanmamış Yüksek Lisans Tezi, Marmara Üniversitesi Eğitim Bilimleri Enstitüsü, İstanbul.

Hart, C., and Blackshaw, P. (2006). Internet Inferno. Marketing Management, (January-February): 19-25.

Hayes, M., Van Stolk-Cooke, K., and Muench, F. (2015). Understanding Facebook Use and The Psychological Effects of Use Across Generations, Computers in Human Behavior, 49: 507-511.

Hughes, D.J., Rowe, M., Batey, M., and Lee, A. (2012). A Tale of Two Sites: Twitter vs. Facebook and The Personality Predictors, Computers in Human Behavior, 28: 561-569.

İçirgin, Ö. (2018). Üniversite Öğrencilerinin Sosyal Medya Kullanım Alışkanlıkları ve Motivasyonları, Yayınlanmamış Yüksek Lisans Tezi, Selçuk Üniversitesi Sosyal Bilimler Enstitüsü Halkla İlişkiler ve Tanıtım Anabilim Dalı, Konya.

Kaplan, A. M., and Haenlein, M. (2010). Users of The World, Unite! The Challenges and Opportunities of Social Media, Business Horizons, 53, 59-68.

Komito, L., and Bates, J. (2009). Virtually Local: Social Media and Community Amongst Polish Nationals in Dublin, Aslib Proceedings: New Information Perspectives, 61(3): 232-244.

Kupperschmidt, B. R. (2000). Multigeneration Employees: Strategies for Effective Management, Health Care Manager, 19(1): 65-76.

Kuyucu, M. (2017). Y Kuşağının İletişim Teknolojilerini Kullanım Alışkanlıkları, Gümüşhane Üniversitesi İletişim Fakültesi Elektronik Dergisi, 5(2): 846-872.

Lower, J. (2008). Brace Yourself Here Comes Generation Y, Critical Care Nurse, 28(5): 80-84.

Mayfield, A. (2008). What is Social Media?. [Online] http://www.icrossing.co.uk/fileadmin/uploads/eBooks/What_is_Social_Media_iCrossing_ebook. pdf $>$ [Erişim Tarihi: 31.07.2018].

Özdamar, K. (2004). Paket Programlar ile İstatistiksel Veri Analizi. Eskişehir: Kaan Kitabevi.

Papacharissi, Z., and Rubin, A. M. (2000). Predictors of Internet Use, Journal of Broadcasting and Electronic Media, 44(2): 175-196.

Sayımer, İ. (2008). Sanal Ortamda Halkla İlişkiler. İstanbul: Beta Yayınları.

Scott, D. M. (2010). The New Rules of Marketing and PR. New Jersey: John Wiley and Sons.

Seifert, A., Doh, M., and Wahl, H.W. (2017). They also Do it: Internet Use by Older Adults Living in Residential Care Facilities, Educational Gerontology, 43(9): 451-461. 
Soylu, Ali. (2018). Endüstri 4.0 ve Girişimcilikte Yeni Yaklaşımlar, Pamukkale Üniversitesi Sosyal Bilimler Enstitüsü Dergisi, 32: 43-57.

Sütlüoğlu, T. (2015). Sosyal Paylaşım Ağlarında Gençlerin Sosyalleşme ve Kimlik İnşası Süreçleri: Facebook Örneği, Folklor/Edebiyat, 21(83): 125-147.

Şahin, A., Kaynakçı, C. ve Aytop, Y. (2016). Ziraat Fakültesi Öğrencilerinin Sosyal Medya Kullanım Alışkanlıklarının Belirlenmesi, Tekirdağ Ziraat Fakültesi Dergisi, 13(2): 34-45.

Yang, K., and Jolly, L. D. (2008). Age Cohort Analysis in Adoption of Mobile Data Services: Gen Xers versus Baby Boomers, Journal of Consumer Marketing, 25(5): 272-280.

Yu, R.P., Ellison, N.B., and McCammon, R.J. (2016) Mapping the Two Levels of Digital Divide: Internet Access and Social Network Site Adoption among Older Adults in the USA, Information, Communication \& Society, 19(10): 1445-1464.

Valenzuela, S., Park, N., and Kee, K. F. (2009). Is There Social Capital in a Social Network Site? Facebook Use and College Student's Life Satisfaction, Trust and Participation, Journal of Computer-Mediated Communication, 14(4): 875-901.

Valkenburg, P. M., Peter, J., and Schouten, A.P. (2006). Friend Networking Sites and Their Relationship to Adolescent's Well-Being and Social Self-Estee, Cyber Psychology and Behavior, 9(5): 584-590.

Vermesan, O., and Friess, P. (2013). Internet of Things-Converging Technologies for Smart Environments and Integrated Ecosystems. Denmark: River Publishers.

Vural, A. Z. B., ve Bat, M. (2010). Yeni Bir İletişim Ortamı Olarak Sosyal Medya: Ege Üniversitesi İletişim Fakültesi'ne Yönelik Bir Araştırma, Journal of Yaşar University, 20(5): 3349-3382.

Weinberg, T. (2009). The New Community Rules: Marketing on the Social Rules. USA: O'Reilly Media.

Williams, C. K., and Page, A. R. (2011). Marketing to the Generations, Journal of Behavioral Studies in Business, 3: 3-11. 